(C) 2018

Мельничук В. В., кандидат ветеринарних наук

Полтавська державна аграрна академія

\title{
МОРФОЛОГІЧНІ ТА МЕТРИЧНІ ОСОБЛИВОСТІ НЕМАТОД НАЕМОNCHUS CONTORTUS (RUDOLPHI 1803) СОВВ 1898, ВИДІЛЕНИХ ВІД ОВЕЦЬ (OVIS ARIES LINNAEUS, 1758)
}

\author{
Рецензент - доктор ветеринарних наук, професор А. А. Замазій
}

\begin{abstract}
Представлені результати визначення особливостей будови імагінальних форм нематод виду Haemonchus contortus (Rudolphi 1803) Cobb 1898, щุo паразитують у домашніх овець (Ovis aries), у кліматичних умовах иентрального та південно-східного регіонів України з урахуванням їх морфометричних показників. Встановлено, що видовими ознаками самиів Н. contortus є особливості у морфологічній будові хвостової бурси, спікул, рулька, статевого конусу, а також їх метричні показники. Самки H. contortus мають специфічну для даного виду варіабельність щзодо структури, форми, розмірів та кількості кутикулярних клапанів в області вульви.
\end{abstract}

Ключові слова: вівиі, Haemonchus contortus, імагінальні форми, нематоди, морфометричні показники.

Постановка проблеми. Збереження біологічного різноманіття у природних та антропогеннотрансформованих екосистемах $є$ одним із пріоритетних завдань сучасної популяційної та прикладної екології. А одними з ключових напрямів практичної реалізації завдань $є$ паразитологічні дослідження і забезпечення ветеринарного благополуччя співчленів ценозу $[1,5]$.

Відомо, що паразитизм - унікальне явище природи. 3 моменту виникнення на Землі гетеротрофних організмів відбувався процес пристосування їх до умов навколишнього середовища. Уже з виникненням життя на планеті відбувається диференціація гетеротрофів на сапрофітів, хижаків та паразитів. Вивчення останніх викликає особливу зацікавленість науковців, оскільки окремі паразити є збудниками інвазійних хвороб рослин, тварин, а також людини. Необхідно також враховувати наявність у паразитів певних морфо-фізіологічних адаптацій до живих істот, яких вони використовують як життєве середовище та як джерело живлення. При цьому, внаслідок взаємного пристосування і в процесі еволюції паразити можуть змінювати свою організацію, що впливає на здатність до зараження, рівень патогенності тощо $[3,4,6]$.

Тому дослідження фауни, біологічних та морфологічних особливостей гельмінтів - паразитів домашніх продуктивних тварин, отримання нових наукових даних сприятиме посиленню контролю епізоотичного стану щодо гельмінтозів та розробці науково-обгрунтованих заходів їх профілактики.

Аналіз останніх досліджень і публікацій, у яких започатковано розв'язання проблеми. Стронгілятози травного тракту, зокрема гемонхоз, $€$ найбільш поширеними гельмінтозами овець на території більшості країн світу $[2,11]$.

Відомо, що на поширеність гемонхозу, а також його антигельмінтикорезистентні властивості впливають екологічні фактори, природнокліматичні умови регіону, де утримуються вівці, а також своєчасне планування та виконання ветеринарних заходів. Науковці свідчать, що збудник гемонхозу - Haemonchus contortus характеризується високою плодючістю, коротким циклом розвитку поколінь, значними пластичними біологічними властивостями. Все це може відображатися на його морфологічній будові, яка може змінюватися внаслідок адаптації або появи резистентності до лікарських засобів $[8,9,10]$.

Більшість авторів вказують на необхідність 3 метою диференціації паразитів даного виду враховувати довжину тіла, у самок - морфологічну будову області вульви, яйцемету, у самців - форму, розмір і будову спікул, наявність рулька, особливості у будові статевої бурси $[7,12]$. Однак необхідно враховувати можливість гемонхусів до адаптації та морфологічних змін у будові їх тіла.

У зв'язку з цим, метою роботи було визначення особливостей морфометричної будови нематод Haemonchus contortus, виділених від овець на території центрального та південно-східного регіонів України.

У завдання досліджень входило встановити морфологічні особливості будови статевозрілих самців та самок; 3'ясувати їх метричні диференційні видові ознаки.

Матеріали і методи досліджень. Дослідження проводилися упродовж 2016-2017 pр. на базі наукової лабораторії кафедри паразитології та 


\section{ВЕТЕРИНАРНА МЕДИЦИНА}

ветеринарно-санітарної експертизи Полтавської державної аграрної академії.

Збір нематод проводили методом повного гельмінтологічного розтину органів травного тракту загиблих або забитих овець, які надходили 3 господарств Полтавської, Київської та Запорізької областей. Вид нематод встановлювали за допомогою визначника за В. М. Івашкіним та ін. (1998). Усього досліджено 1472 екземпляри статевозрілих нематод Haemonchus contortus, 3 них: 834 - самки, 638 - самців.

Біометрію нематод проводили із застосуванням об'єкт-мікрометра, окуляр-мікрометра і мікроскопа у випадку збільшення Ч 50, Ч 100 , Ч 400. Мікрофотографування проводили за допомогою цифрової камери до мікроскопу MICROmed 3Mpix (China).

Результати досліджень. За результатами паразитологічних досліджень виділених від овець нематод Haemonchus contortus встановлено, що їм характерна специфічна морфологічна будова. Так, спільною для статевозрілих самців та самок видовою ознакою виявилася наявність достатньо крупних шийних сосочків на головному кінці. Ротова порожнина містить один зуб. Також біля шийних сосочків з одного боку знаходиться екскреторний отвір (рис. 1).

У імагінальних форм самців нематод характе- рними видовими морфологічними ознаками $\epsilon$ особливості форми, структури та розмірів хвостової бурси, спікул, а також до диференційної ознаки можна віднести наявність рулька та статевого конусу (рис. 2).

Хвостова бурса трилопатева, добре розвинена, 3 двома чітко вираженими латеральними ребрами та невеликим, асиметрично розташованим дорсальним ребром. Вентральні ребра виходять 3 одного стовбура. Екстерно-дорсальні ребра тонкі, довгі, відгалужуються самостійно від дорсального ребра. Спікули короткі, масивні. Їх проксимальний кінець розширений, зігнутий, кінець притуплений, а дистальний - потоншений, закінчуються шароподібним потовщенням, містить гострий шипик. Рульок має човникоподібну форму.

Визначено метричні показники самців H. contortus, які дадуть змогу підвищити та спростити диференційну видову діагностику (табл. 1).

Так, середня довжина тіла самців становила $18,27 \pm 0,36$ мм. Запропоновано вимірювати ширину у різних ділянках тіла, а саме: в області шийних сосочків, екскреторного отвору, переходу стравоходу в кишечник, перед статевою бурсою, а також розміри найширшої ділянки тіла.

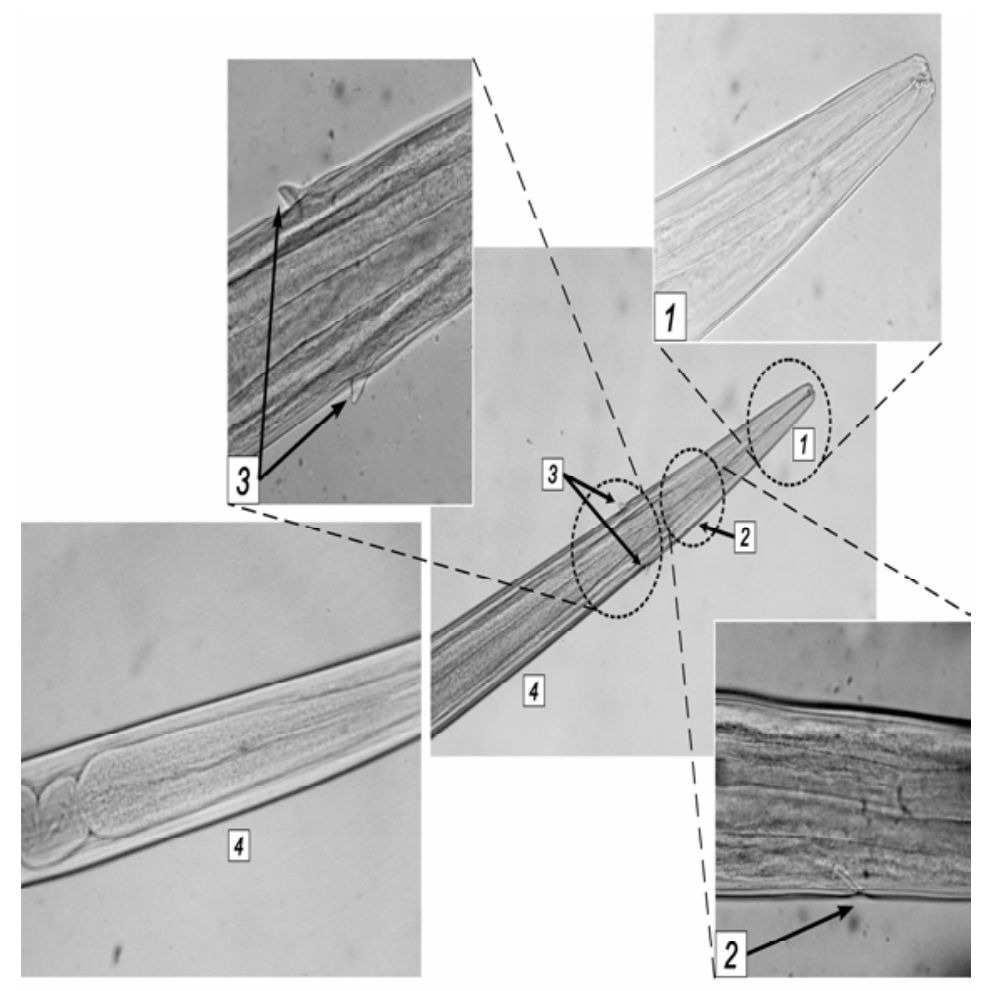

Рис. 1. Головний кінець Наетопсhus contortus (Ч 100; Ч 400): 1 -ротовий отвір, 2 - екскреторний отвір, 3 - иийні сосочки, 4 - бульбус 


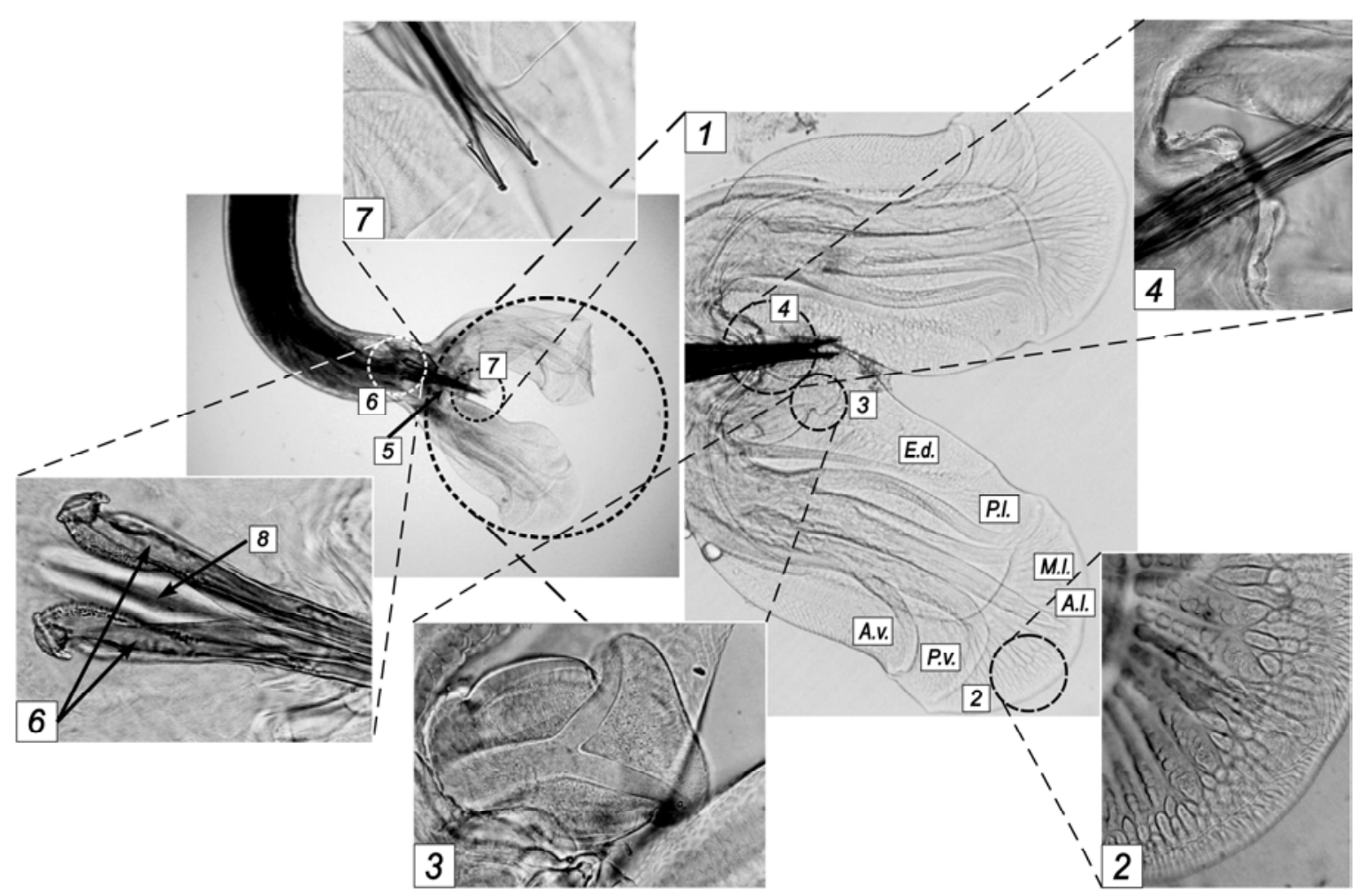

Pис. 2. Хвостовий кінець самця Haеmonchus contortus (Ч 50; Ч 100; Ч 400):

1 -хвостова бурса, 2 - візерунчастість кутикули, 3 - дорсальне ребро,

4 - статевий конус, 5 -спікули, 6 - проксимальний кінець спікули,

7 - дистальний кінець спікули, 8-рульок, А.v. - антеро-вентральне ребро,

P.v. - постеро-вентральне ребро, A.l. - антеро-вентральне ребро,

M.l. - медіо-латеральне ребро, P.l. - постеро-латеральне ребро,

E.d. - екстерно-дорсальне ребро

Встановлено, що параметри ширини тіла коливалися від 90,91 $\pm 0,41$ до $314,72 \pm 4,64$ мкм. Також необхідно враховувати розміри шийних сосочків (20,32 $\pm 0,48$ Ч 20,32 $\pm 0,48$ мкм) та розміри лопатей статевої бурси (за коливань від 236,61 $\pm 3,86$ Ч

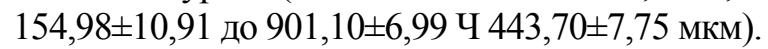

Розміри спікули становили: довжина -

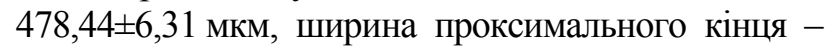
$40,12 \pm 0,37$ мкм, ширина дистального кінця $13,32 \pm 0,18$ Ч 14,22 $\pm 0,16$ мкм. Характерним морфологічним утворенням на спікулах самців $€$ наявність гострого шипику, а метричними - їх довжина, яка на правій спікулі становила $41,38 \pm 0,32$ мкм, а на лівій $-22,41 \pm 0,43$ мкм. Водночас ширина статевого

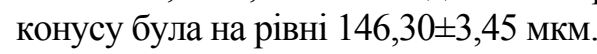

Самки нематод Н. contortus за морфологічною будовою мають добре розвинений яйцемет, вульва знаходиться в задній частині тіла і прикрита язикоподібним кутикулярним клапаном. Хвостовий кінець конічної форми, звужений, прямий, без будь-яких утворень (рис. 3 a). Характерною була наявність декількох кутикулярних клапанів в області вульви, які різнилися за формою, розташуванням та структурою (рис. 3 b).
Враховуючи отримані метричні показники самок H. Contortus, можна спростити проведення їх диференційної діагностики (табл. 2). Так, довжина тіла самок, в середньому, становила $27,13 \pm 0,43$ мм за коливань ширини у різних ділянках тіла від $95,81 \pm 0,92$ до 445,29 $\pm 17,23$ мкм. Необхідно також враховувати розміри кутикулярних клапанів, оскільки вони мають значну варіабельність по кількості та формі. Довжина та ширина вентрального клапану дорівнювали відповідно $762,70 \pm 27,49$ та $296,20 \pm 4,54$ мкм, а дорсального клапану $230,70 \pm 3,86$ та $247,09 \pm 7,50$ мкм.

Встановлено, що розміри яйцемету у самок даного виду нематод становили $813,07 \pm 27,08$ ч $101,83 \pm 2,26$ мкм. Особливістю є вимірювання відстані від хвостового кінця до анального отвору $(484,15 \pm 11,28$ мкм), а також від вульви до хвостового кінця $(6,17 \pm 0,25$ мкм). Розміри яєць нематод, також мають диференційне значення у встановленні видової приналежності гельмінтів. Так, довжина гонадних яєць у H. contortus становила $81,17 \pm 0,82$ мкм у випадку ширини $43,20 \pm 0,49$ мкм. 
ВЕТЕРИНАРНА МЕДИЦИНА

\section{1. Метричні видові показники самців Наетоnchus contortus, виділених від овець (n=15)}

\begin{tabular}{|l|c|c|}
\hline \multicolumn{1}{|c|}{ Показники } & \multicolumn{2}{c|}{ Розміри } \\
\cline { 2 - 3 } & $\mathrm{M} \pm \mathrm{m}$ & Min-max \\
\hline Довжина тіла, мм & $18,27 \pm 0,36$ & $16,00-20,50$ \\
\hline Відстань від головного кінця до шийних сосочків, мкм & $451,47 \pm 0,35$ & $448,69-453,08$ \\
\hline Ширина тіла в області шийних сосочків, мкм & $103,48 \pm 0,65$ & $100,68-108,64$ \\
\hline Довжина шийних сосочків, мкм & $20,32 \pm 0,48$ & $17,25-23,18$ \\
\hline Відстань від головного кінця до екскреторного каналу, мкм & $369,04 \pm 1,15$ & $359,67-374,60$ \\
\hline Ширина тіла в області екскреторного отвору, мкм & $90,91 \pm 0,41$ & $87,47-93,36$ \\
\hline Відстань від екскреторного каналу до шийних сосочків, мкм & $83,64 \pm 1,01$ & $77,36-89,47$ \\
\hline Довжина стравоходу, мм & $1,61 \pm 0,02$ & $1,49-1,75$ \\
\hline Ширина тіла в області переходу стравоходу & $205,81 \pm 2,13$ & $190,78-217,66$ \\
в кишечник, мкм & $314,72 \pm 4,64$ & $290,72-358,78$ \\
\hline Максимальна ширина тіла, мкм & $287,30 \pm 3,38$ & $253,56-301,58$ \\
\hline Ширина тіла перед статевою бурсою, мкм & $901,10 \pm 6,99$ & $836,80-924,08$ \\
\hline Довжина латеральних лопатей статевої бурси, мкм & $443,70 \pm 7,75$ & $404,83-501,68$ \\
\hline Ширина латеральних лопатей статевої бурси, мкм & $236,61 \pm 3,86$ & $206,09-261,33$ \\
\hline Довжина дорсальної лопаті статевої бурси, мкм & $154,98 \pm 10,91$ & $128,94-259,87$ \\
\hline Ширина дорсальної лопаті статевої бурси, мкм & $146,30 \pm 3,45$ & $129,03-167,78$ \\
\hline Ширина статевого конусу, мкм & $478,44 \pm 6,31$ & $423,31-511,34$ \\
\hline Довжина спікули, мкм & $40,12 \pm 0,37$ & $37,75-43,19$ \\
\hline Ширина проксимального кінця спікули, мкм & $41,38 \pm 0,32$ & $39,47-43,97$ \\
\hline Довжина шипика на дистальному кінці правої спікули, мкм & $13,32 \pm 0,18$ & $12,08-14,55$ \\
\hline Ширина шипику на дистальному кінці правої спікули, мкм & $22,41 \pm 0,43$ & $20,66-25,39$ \\
\hline Довжина шипика на дистальному кінці лівої спікули, мкм & $14,22 \pm 0,16$ & $13,11-15,25$ \\
\hline Ширина шипику на дистальному кінці лівої спікули, мкм & & \\
\hline
\end{tabular}

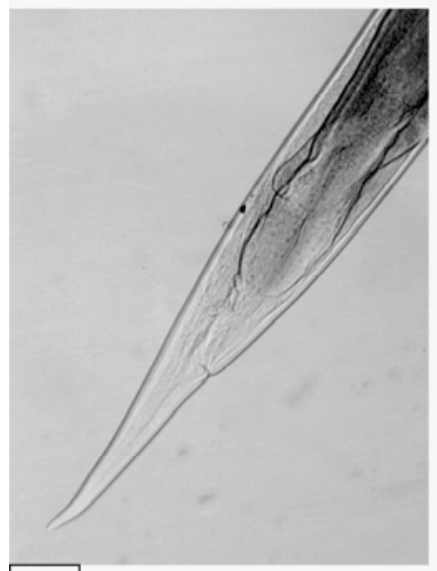

a
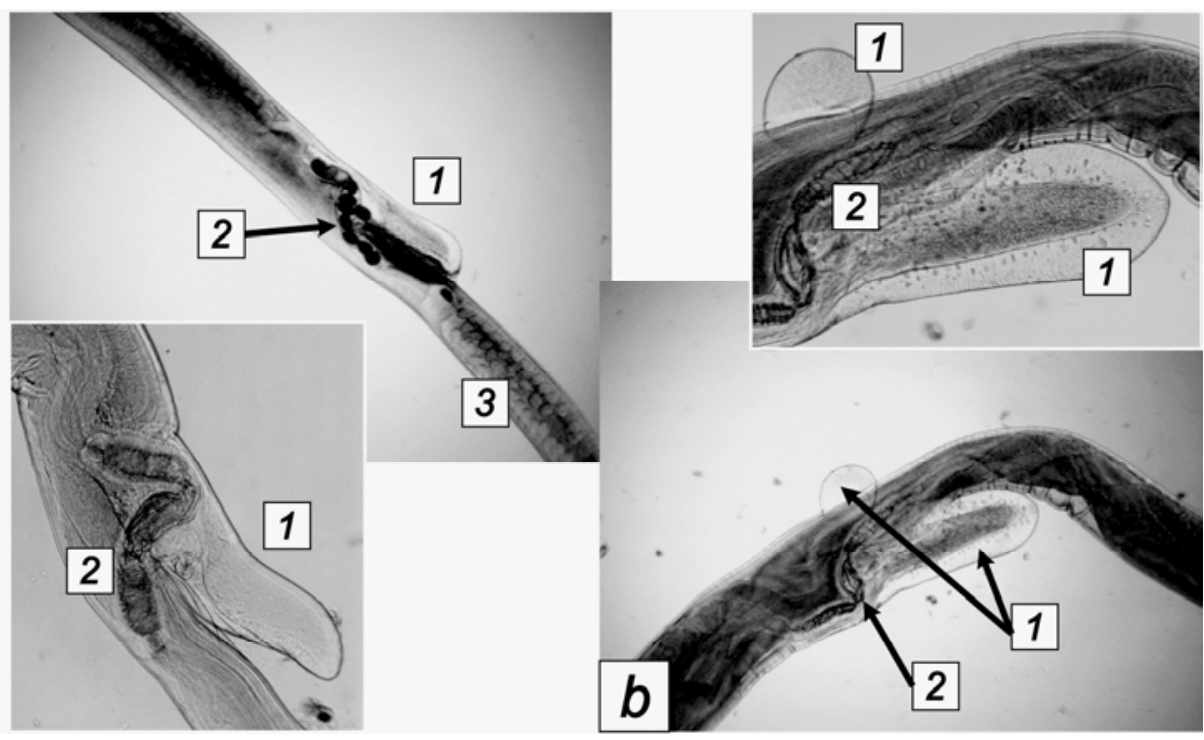

Рис. 2. Морфологічна будова самки

Haemonchus contortus:

a-хвостового кінця (Ч100), b-області вульви (Ч50; Ч100):

1 - кутикулярні клапани, 2 - яйцемет,

3 - яйця в порожснині матки 
2. Метричні видові показники самок Наетоnchus contortus, виділених від овець $(n=15)$

\begin{tabular}{|l|c|c|}
\hline \multicolumn{1}{|c|}{ Показники } & \multicolumn{2}{c|}{ Розміри } \\
\cline { 2 - 3 } & $\mathrm{M} \pm \mathrm{m}$ & Min-max \\
\hline Довжина тіла, мм & $27,13 \pm 0,43$ & $24,50-30,00$ \\
\hline Відстань від головного кінця до шийних сосочків, мкм & $482,36 \pm 3,92$ & $452,89-502,66$ \\
\hline Ширина тіла в області шийних сосочків, мкм & $118,54 \pm 0,98$ & $109,24-122,60$ \\
\hline Довжина шийних сосочків, мкм & $27,57 \pm 0,71$ & $22,27-30,62$ \\
\hline Відстань від головного кінця до екскреторного каналу, мкм & $378,65 \pm 1,23$ & $370,95-387,18$ \\
\hline Ширина тіла в області екскреторного каналу, мкм & $95,81 \pm 0,92$ & $89,66-101,34$ \\
\hline Відстань від екскреторного каналу до шийних сосочків, мкм & $86,08 \pm 0,86$ & $80,60-90,45$ \\
\hline Довжина стравоходу, мм & $1,56 \pm 0,02$ & $1,45-1,74$ \\
\hline Ширина тіла в області переходу стравоходу в кишечник, мкм & $217,51 \pm 4,55$ & $195,46-241,69$ \\
\hline Ширина тіла в області вульви, мкм & $445,29 \pm 17,23$ & $339,01-527,69$ \\
\hline Відстань від вульви до хвостового кінця, мм & $6,17 \pm 0,25$ & $5,00-7,50$ \\
\hline Довжина вентрального язикоподібного клапану, мкм & $762,70 \pm 27,49$ & $503,56-871,41$ \\
\hline Ширина вентрального язикоподібного клапану, мкм & $296,20 \pm 4,54$ & $261,27-325,88$ \\
\hline $\begin{array}{l}\text { Співвідношення ширини до довжини вентрального язико- } \\
\text { подібного клапану, мкм }\end{array}$ & $1: 2,58$ & $1: 1,87 ; 3,05$ \\
\hline Довжина яйцемету з м'язовою частиною, мкм & $813,07 \pm 27,08$ & $628,97-955,21$ \\
\hline Ширина яйцемету, мкм & $101,83 \pm 2,26$ & $88,21-124,6$ \\
\hline Довжина дорсального клапану, мкм & $230,70 \pm 3,86$ & $207,49-250,22$ \\
\hline Ширина дорсального клапану, мкм & $247,09 \pm 7,50$ & $154,33-270,37$ \\
\hline Відстань від хвостового кінця до анального отвору, мм & $484,15 \pm 11,28$ & $399,33-549,50$ \\
\hline Ширина тіла в області анального отвору, мкм & $107,77 \pm 1,34$ & $98,45-115,43$ \\
\hline Довжина гонадних ясць, мкм & $81,17 \pm 0,82$ & $75,46-86,92$ \\
\hline Ширина гонадних яєць, мкм & $43,20 \pm 0,49$ & $40,69-46,92$ \\
\hline
\end{tabular}

Отже, визначення морфологічних і метричних параметрів нематод виду Haemonchus contortus дасть можливість ефективно проводити диференційну діагностику паразитів.

Висновки:

1. Встановлено, що нематоди виду Haemonchus contortus, що паразитують у овець, мають видові специфічні морфологічні та метричні параметри, характерні як для самців, так і для самок, а саме: розміри тіла, стравоходу, наявність та розміри шийних сосочків.

2. Диференційними морфометричними ознаками статевозрілих самців H. contortus є форма,

\section{БІБЛІОГРАФІЯ}

1. Адаптационные процессы и паразитозы животных : монография / А. И. Ятусевич [и др.]. Витебск : УО ВГАВМ, 2006. - 404 с.

2. Байсарова 3. T. Распространение гемонхоза в овцеводческих хозяйствах Чеченской Республики, биоэкология Haemonchus contortus // Pocсийский паразитол. журнал. - 2011. - №2. C. 21-23.

3. Маркевич А. П. Происхождение и эволюция паразитизма / А. П. Маркевич // Труды Башкирск. структура та розміри статевої бурси, спікул, рулька та статевого конусу.

3. Диференційними видовими ознаками статевозрілих самок $H$. contortus є морфологічна будова та метричні показники яйцемету, яєць, кутикулярних клапанів в області вульви з урахуванням їх варіабельності.

Перспективи подальшої роботи в иьому напрямі. Перспективами подальших досліджень $€$ встановлення видового складу стронгілят органів травлення овець на території центрального та південно-східного регіонів України.

науч. исслед. вет. станции. - 1943. - Т. 4. - С. 3-68.

4. Павловский Е. Н. Условия и факторы становления организма хозяином паразита в процессе эволюции / Е. Н. Павловский // Зоологический журнал - 1946. - Т. 25, вып. 4. - С. 290.

5. Пепко В. О. Гельмінтофауна диких копитних тварин: екологія, видовий склад, поширення (оглядова стаття) / В. О. Пепко, С. В. Жигалюк, Р. М. Сачук, I. Т. Гулик // Ветеринарна біотехнологія. - 2017. - Вип. 30. - С. 183-195. 


\section{ВЕТЕРИНАРНА МЕДИЦИНА}

6. Приходько T. М. Генезис терміну паразитизм / Т. М. Приходько // Історія освіти, науки і техніки в Україні : третя наук. конф. молодих учених та спеціалістів, 26-27 трав. 2006 р., м. Київ. - К., 2006. - С. 39.

7. A Brief Study of Morphology of Haemonchus contortus and its Hematophagous Behaviour / [Irfan-ur-Rauf Tak, Dar S. A., J. S., Ganai B. A. et al.] // Global Veterinaria. - 2014. - Vol. 13 (6). P. 960-965.

8. A one shot blood phenotype can identify sheep that resist Haemonchus contortus challenge / [Andronicos N. M., Henshall J. M., Le Jambre L. F. et al.] // Veterinary Parasitology. - 2014. - Vol. 205. P. 595-605.

9. Adams D. B. Systemic responses to challenge infection with Haemonchus contortus in immune
Merino sheep / D. B. Adams // Veterinary Research Communications. - 1993. - Vol. 17. - P. 25-35.

10. Bargerm I. A. Resistance of young lambs to Haemonchus contortus infection, and its loss following anthelmintic treatment / I. A. Barger // International Journal for Parasitology. - 1988. Vol. 18. - P. 1107-1109.

11. Peter J. W. Haemonchus contortus: parasite problem № 1 from tropics - Polar Circle. Problems and prospects for control based on epidemiology / J. W. Peter, P. Chandrawathani // Tropical Biomedicine. - 2005. - Vol. 22 (2). - P. 131-137.

12. Zajac A. M. Gastrointestinal nematodes of small ruminants: life cycle, anthelmintics and diagnosis / A. M. Zajac // Veterinary Clinics of North America: Food Animal Practice. - 2006. Vol. 22. - P. 529-541. 